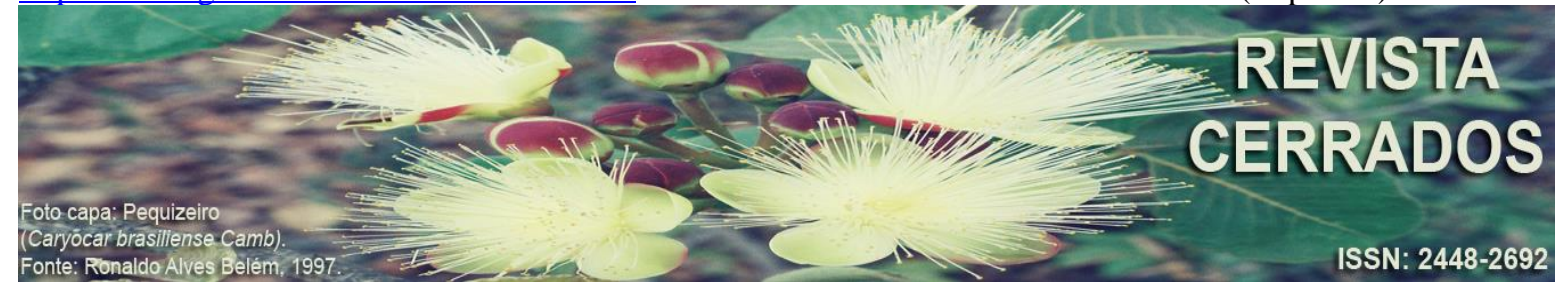

\title{
DIFERENÇAS ETNOCULTURAIS NA ESCOLA: Experiências de alunos Xakriabá em um espaço escolar não indígena ${ }^{1}$
}

\section{ETHNOCULTURAL DIFFERENCES IN SCHOOL: Experiences of Xakriabá students in a non-indigenous school space}

\section{DIFERENCIAS ETNOCULTURALES EN LA ESCUELA: Experiencias de estudiantes Xakriabá en un espacio escolar no indígena}

\author{
Leonardo José dos R. C. de Melo \\ Universidade Federal de Goiás - UFG, Goiânia, Goiás, Brasil \\ E-mail: <leodemelo87@gamail.com>.
}

\author{
Ademir Divino Vaz \\ Universidade Estadual de Goiás - UEG, Pires do Rio, Goiás, Brasil \\ E-mail: <ademirvaz@hotmail.com>. \\ Maria Geralda de Almeida \\ Universidade Federal de Goiás - UFG, Goiânia, Goiás, Brasil \\ E-mail: <mgdealmeida10@gmail.com>.
}

\begin{abstract}
RESUMO
No espaço escolar se formam relações e encontros socioculturais distintos e a partir disso conflitos podem ser detectados. Realizou-se algumas reflexões com base em um levantamento preliminar acerca da maneira como as relações entre os indígenas da etnia Xakriabá e alunos não índios ocorrem em um espaço escolar não indígena. Metodologicamente a pesquisa se caracteriza como qualitativa e explicativa, utilizando como método de análise a fenomenologia e acessando os valores simbólicos e subjetivos que envolvem os construtos sociais destes indivíduos, perfilando-os nos pressupostos da Geografia Humanista Cultural. Utilizou-se de levantamento bibliográfico e trabalho de campo. Identificou-se na pesquisa evidências de que a diferença etnocultural transfigura-se em elemento que desperta conflitos, atos de racismo $e$ bullying no espaço escolar. Isso torna importante dar visibilidade aos grupos de estudantes considerados como não hegemônicos, neste caso os alunos Xakriabá, para que

\footnotetext{
${ }^{1} \mathrm{O}$ texto apresenta os resultados do trabalho monográfico intitulado (Des)Encontros no ambiente escolar: Xakriabá no Instituto Federal Goiano Campus Urutaí (2019), sob a orientação do professor Me. Ademir Divino Vaz, realizado em parceria com o Laboratório de Estudos Étnicos (LABETI), Universidade Estadual de Goiás Campus Pires do Rio.
} 
MELO, L. J. R. C.; VAZ, A. D.; ALMEIDA, M. G.

Diferenças etnoculturais na escola: Experiências de alunos Xakriabá em um espaço escolar não indígena

possam apontar atos preconceituosos contra sua etnia e reivindiquem suas demandas, no ambiente escolar.

Palavras-chave: Diferenças étnicas. Encontros interétnicos. Ambiente escolar.

\begin{abstract}
In the school environment, distinct sociocultural relationships and encounters are formed and from that conflicts can be detected. In this study, reflections were made based on a preliminary survey about the way in which the relations between the Xakriabá indigenous people and non-Indian students occur in a non-indigenous school environment. Methodologically, the research can be characterized as qualitative and explanatory, phenomenology was used as the method of analysis to access the symbolic and subjective values involve in the social constructs of these individuals, profiling them on the assumptions of Humanistic Cultural Geography. Bibliographic surveys and fieldwork were used. Evidence was found suggesting that ethnocultural differences turn out to be ne an element that results in conflicts such as racism and bullying in the school space. From such interactions, the importance of giving visibility to groups of students considered to be non-hegemonic, in this case the Xakriabá emerges so that they can point out prejudiced acts against their ethnicity and claim their demands in the school environment.
\end{abstract}

Keywords: Ethnic differences. Interethnic encounters. School environment.

\title{
RESUMEN
}

En el espacio escolar se forman distintas relaciones y encuentros socioculturales y a partir de ese conflicto se pueden detectar. En este estudio se hicieron algunas reflexiones de una encuesta preliminar sobre la forma en que se dan las relaciones entre estudiantes del pueblo indígena Xakriabá y los demás estudiantes en un espacio escolar no indígena. Metodológicamente la investigación se caracteriza por ser cualitativa y explicativa, utilizando la fenomenología como método de análisis y accediendo así a los valores simbólicos y subjetivos que involucran los constructos sociales de estos individuos, perfilándolos en los supuestos de la Geografía Cultural Humanista. Se utilizaron encuestas bibliográficas y trabajo de campo. Se identificó en la investigación, evidencia de que la diferencia etnocultural se convierte en un elemento que despierta conflictos, racismo y bullying en el espacio escolar. Esto hace que sea importante dar visibilidad a los grupos de estudiantes considerados no hegemónicos, en este caso estudiantes Xakriabá, para que así puedan señalar actos prejuiciados contra su etnia y reivindicar sus demandas mientras convive con no indígenas.

Palabras-clave: Diferencias étnicas. Encuentros interétnicos. Ambiente escolar.

\section{INTRODUÇÃO}

É evidente em nossa sociedade o processo de invisibilização dos povos indígenas ao longo da formação histórica do Brasil, enquanto povo e nação. As demandas dos povos 
MELO, L. J. R. C.; VAZ, A. D.; ALMEIDA, M. G.

Diferenças etnoculturais na escola: Experiências de alunos Xakriabá em um espaço escolar não indígena

indígenas são, na maioria dos casos, negligenciadas. E no espaço escolar não tem sido diferente, em especial quando alunos indígenas tem a necessidade de procurar escolas fora dos seus territórios tradicionais.

Os alunos indígenas acabam sofrendo com discursos de ódio, atos de discriminação e bullying, situações que se tornam parte de uma triste realidade vivida por estes estudantes dentro da escola. Buscar compreender de que maneira se dão e como são construídas as relações entre o aluno indígena e o não índio, assim como compreender a forma como o indígena apropria-se do espaço escolar, contribui para visibilizar as demandas e necessidades destes alunos.

As reflexões apresentadas são decorrentes de pesquisa realizada durante o ano de 2019, tendo como área de estudo o Instituto Federal Goiano Campus Urutaí (IF Goiano Urutaí). Instituição esta que recebe alunos indígenas, em especial da etnia Xakriabá. Os alunos Xakriabá residem no município de São João das Missões, região Norte do estado de Minas Gerais, e embora existam outras instituições de ensino superior na região desde o ano de 2014, eles buscam no IF Goiano - Urutaí a oportunidade de continuarem seus estudos. Isso ocorre por conta de uma parceria realizada entre as autoridades locais da etnia Xakriabá e as autoridades do IF Goiano - Urutaí, e, neste novo ambiente encontram um espaço dominado culturalmente por práticas e costumes do não índio.

A investigação realizada, enquanto levantamento preliminar, procurou compreender de que forma as relações entre alunos indígenas e não índios são construídas a partir do contato e da convivência entre estes dois grupos no espaço escolar. Dessa maneira o trabalho busca visibilizar as experiências e percepções dos alunos da etnia Xakriabá, como são recebidos e percebidos no ambiente escolar, ambiente composto predominantemente por alunos não indígenas, observando a maneira como ocorre a interação entre estes sujeitos, a partir de suas diferenças etnoculturais.

Esta pesquisa também busca expressar como as diferenças etnoculturais interferem na convivência entre alunos indígenas e não índios, refletindo acerca dos principais conflitos ocorridos a partir desta relação interétnica, no intuito de que estas reflexões sirvam de alicerce para a elaboração de propostas destinadas à plena inserção dos alunos indígenas no espaço escolar não indígena.

O embasamento teórico constituiu-se de leituras e análises de trabalhos já produzidos acerca do tema na Base de Artigos Científicos da Coordenação de Revista Cerrados, Montes Claros/MG, v. 18, n. 02, p. 344-370, jul./dez.-2020. 
MELO, L. J. R. C.; VAZ, A. D.; ALMEIDA, M. G.

Diferenças etnoculturais na escola: Experiências de alunos Xakriabá em um espaço escolar não indígena

Aperfeiçoamento de Pessoal de Nível Superior (Capes) e na Biblioteca Digital Brasileira de Teses e Dissertações (BDTD), entre os autores que contribuíram para a realização das reflexões estão: Correa Xakriabá (2018) Campos, Silva e Silva (2018), Ramalho (2015), Silveira e Nardi (2014), Candau (2008), Rocha e Almeida (2005), Ribeiro (2004) e Gomes (2003). Outros dados relacionados a localização e deslocamento dos alunos Xakriabá foram coletados nos sites do Sistema Estadual de Geoinformação de Goiás (SIEG/Go), Instituto Brasileiro de Geografia e Estatística (IBGE) e Fundação Nacional do Índio (FUNAI), contribuindo para a elaboração de mapas.

A pesquisa enquadra-se no tipo explicativa e objetiva pormenorizar o fenômeno socioespacial, aprofundando o conhecimento existente, "[...] este é o tipo de pesquisa que mais aprofunda o conhecimento da realidade, porque explica a razão, o porquê das coisas" (GIL, 2008, p. 28). Os dados empíricos foram coletados durante trabalho de campo. Os dados empíricos foram coletados durante trabalho de campo, quando foram aplicados questionários semiestruturados aos alunos indígenas e aos professores. O questionário constituiu-se de oito perguntas de múltipla escolha, assim como de perguntas discursivas, para que expressassem suas experiências a partir da convivência e socialização neste espaço. Dispuseram-se a responder aos questionários dez alunos Xakriabá.

Após a aplicação, todos os questionários foram organizados de maneira aleatória, os quais posteriormente foram classificados em sequência alfabética, sendo esta a maneira com que será apresentada a autoria das transcrições das respostas discursivas. Embora o grupo de estudantes da etnia Xakriabá, possua alunas do sexo feminino, se obteve retorno apenas dos alunos do sexo masculino, estes que compreendem a faixa etária dos 15 aos 18 anos.

Aos professores do IF Goiano - Urutaí foram aplicados questionários, contendo oito questões de múltipla escolha e também abarcando perguntas discursivas, para que expressassem percepções acerca da interação entre alunos indígenas Xakriabá e os não índios e pudessem compartilhar as atividades que realizam em suas aulas para abordar temas relacionados à diversidade cultural e étnica.

Houve participação de doze professores, sendo onze mulheres e um homem. A idade destes profissionais se diversificou de 24 a 43 anos, entre o profissional mais jovem e o com mais idade. $\mathrm{O}$ modelo de pesquisa caracteriza-se como qualitativo, o método de análise perfilou pela fenomenologia e a abordagem está assentada nos pressupostos teóricos da Geografia Humanista Cultural.

Revista Cerrados, Montes Claros/MG, v. 18, n. 02, p. 344-370, jul./dez.-2020. 
MELO, L. J. R. C.; VAZ, A. D.; ALMEIDA, M. G.

Diferenças etnoculturais na escola: Experiências de alunos Xakriabá em um espaço escolar não indígena

A estrutura traz, de início, uma reflexão que se alinha pelas origens étnicas do povo brasileiro e a estruturação do espaço vivido, em sequência explora a articulação possível entre espaço vivido e espaço escolar, além dos encontros socioculturais possíveis no ambiente escolar. Ao prosseguir, traça um breve histórico do povo Xakriabá e o seu processo de escolarização, até o momento da chegada desses alunos ao IF Goiano Campus Urutaí, apresentando os dados coletados durante trabalho de campo. Por fim são apresentadas as considerações finais, contemplando a análise integral com as reflexões realizadas.

\section{Etnia, Cultura e Espaço}

Compreender acerca da formação étnica da população brasileira faz-se necessário para atingir a atual estrutura social dos grupos e sua organização. Silveira e Nardi (2014) apresentam que o conceito de etnia está associado com questões relativas à identidade de cada povo e suas práticas culturais, estabelecendo uma relação de fronteira com outros grupos. $\mathrm{O}$ lugar e o espaço vivido, enquanto lócus de origem, tornam-se estruturas importantes para elaboração deste conceito.

A origem étnica da população brasileira, de acordo com Ribeiro (1995), se dá a partir de três matrizes principais: indígenas, europeus e africanos, cada qual com práticas culturais distintas, "Cultura, aqui, é definida pelas relações históricas de um povo, que dão sentido ao mundo-vivido num território que se torna lugar" (ROCHA; ALMEIDA, 2005, p. 12).

O espaço vivido associa-se as interconexões dos elementos geográficos, conectando-o as dimensões naturais, sociais e culturais, e funde-se com os espaços da imaginação e projeção, "É um espaço concreto, porque vivido é único e não único, persistente e mutável, faz parte de nós e está à parte de nós. O mundo vivido, sendo a expressão de nossas experiências, está associado a sentimentos de prazer ou desprazer" (SUERTEGARAY, 2005, p. 31). Analisar o espaço enquanto vivido possibilita acessar os valores simbólicos e subjetivos que os sujeitos conferem a este, permitindo uma percepção mais ampla das dificuldades e anseios destes indivíduos.

Desse modo, compreender como ocorre a interação entre alunos indígenas e alunos não índios no espaço escolar não indígena, permite acessar os valores subjetivos à percepção desses sujeitos acerca desse espaço, corroborando para uma apreensão mais Revista Cerrados, Montes Claros/MG, v. 18, n. 02, p. 344-370, jul./dez.-2020. 
MELO, L. J. R. C.; VAZ, A. D.; ALMEIDA, M. G.

Diferenças etnoculturais na escola: Experiências de alunos Xakriabá em um espaço escolar não indígena

particular de como estas relações se estruturam e se desdobram. Neste sentido considera-se de extrema importância as experiências dos indivíduos envolvidos, os estudantes Xakriabá, visto que as experiências possuem estreita ligação com as atitudes.

O espaço escolar é por essência um ambiente de encontros socioculturais, dada a própria diversidade da população brasileira e, "a diversidade cultural se faz presente na sociedade, sendo que, cada grupo, cada povo, tem suas peculiaridades, e expressam das formas mais variadas os seus valores culturais." (RAMALHO, 2015, p. 30). Os temas relacionados à diversidade cultural na escola fazem-se de grande relevância, pois estimulam o pensar acerca de como os diferentes grupos são recebidos, como os outros alunos reconhecem e percebem o diferente neste espaço e se todos os grupos se sentem representados.

Gomes (2003, p. 69, grifo da autora) assinala as seguintes questões:

A reflexão sobre educação e diversidade cultural não diz respeito apenas ao reconhecimento do outro como diferente. Significa pensar a relação entre eu e o outro. A escola é um dos espaços socioculturais em que as diferenças presenças se encontram. Mas será que essas diferenças têm sido respeitadas? Será que a garantia da educação escolar como um direito social possibilita a inclusão de todo tipo de diferença dentro desse espaço?

A reflexão sobre educação e diversidade cultural não diz respeito apenas ao reconhecimento do outro como diferente. Significa pensar a relação entre eu e o outro. A escola é um dos espaços socioculturais em que as diferenças presenças se encontram. Mas será que essas diferenças têm sido respeitadas? Será que a garantia da educação escolar como um direito social possibilita a inclusão de todo tipo de diferença nesse espaço? Seguindo o raciocínio da autora, indagações surgem sobre essa relação entre indígenas e não indígenas no ambiente escolar, tais quais: como ocorrem as relações entre os sujeitos deste Instituto? As diferenças são respeitadas?

O Instituto Nacional de Colonização e Reforma Agrária (INCRA, 2015) expressa que se faz necessário refletir acerca das regras sociais que cada grupo étnico possui, algo que é estabelecido pelas tradições nas quais cada comunidade está envolvida e se desenvolve.

\section{O Espaço Escolar como Espaço Vivido}

Ao aprofundar as reflexões no sentido de espaço escolar compreende-se a articulação e a dinâmica entre este e o espaço vivido. Nessas duas categorias de análise do 
MELO, L. J. R. C.; VAZ, A. D.; ALMEIDA, M. G.

Diferenças etnoculturais na escola: Experiências de alunos Xakriabá em um espaço escolar não indígena

espaço se faz presente as vivências e experiências dos sujeitos, o cotidiano e as experiências pessoais e interpessoais influenciam na percepção e apropriação do espaço.

De acordo com Ribeiro (2004, p. 103);

o espaço escolar é visto como uma fonte de experiências e de aprendizagem que, em sua materialidade, está impregnado de signos, símbolos e marcas que comunicam e educam; a sua produção distribuição, posse e usos têm um importante papel pedagógico.

Demonstrando a partir da autora que os espaços são para os sujeitos da mesma forma que os sujeitos são para com os espaços. O espaço escolar, segundo Viñao Frago e Escolano (2001), deve ser considerado enquanto uma construção cultural cheia de reflexos, que transpõe sua estrutura físico-material. Neste contexto, teorias pautadas na percepção tornam-se suporte indispensável, sempre ressaltando este espaço também como um mediador cultural de formação dos primeiros esquemas cognitivos e motores, uma fonte importante de experiências e aprendizagem.

Torna-se importante ampliar a concepção levantada por Viñao Frago e Escolano (2001) e apreender o espaço escolar não apenas como um mediador dos primeiros esquemas cognitivos e motores, mas também como um espaço que extrapola a mera ideia de convivência. Os indivíduos passam vários anos de suas vidas inseridos no ambiente escolar e este período pode representar momentos de experiências positivas ou negativas, que os sujeitos levam ao longo de suas vidas.

De acordo com Silva e Lopes (2014, p. 14), é pessoal a percepção que o sujeito possui do ambiente, pois depende das experiências que este previamente possui. Pode-se constatar isso a partir de como dois indivíduos diferentes, com históricos de vida e atitudes distintas, percebem um mesmo ambiente de forma diferenciada, pois sua percepção baseia-se imprescindivelmente em suas vivências.

É necessário analisar o espaço escolar e as relações sociais construídas, observando sempre as diferenças culturais, étnicas e a ocorrência de possíveis conflitos. A escola deve atender a um todo, de forma coerente, visto que ali desenvolvem-se práticas pedagógicas, construindo um ambiente de possibilidades ou de limites. Para Ribeiro (2004, p. 103), “o espaço não é neutro e está impregnado de signos, símbolos e marcas de quem o produz, organiza e nele convive por isso, tem significações e marcas de quem o elabora, organiza e nele convive, por isso, tem significações afetivas e culturais". 
MELO, L. J. R. C.; VAZ, A. D.; ALMEIDA, M. G.

Diferenças etnoculturais na escola: Experiências de alunos Xakriabá em um espaço escolar não indígena

Moura e Zucchetti (2010) afirmam que situações de conflitos entre diferentes grupos ocorrem, também, na escola, em decorrência dessa instituição apropriar-se de valores sociais da cultura hegemônica, proclamando-os como eruditos e padrão. Por conseguinte, considera as culturas populares desviantes, inferiores e até subversivas. Porém, mesmo que a escola apresente os valores culturais do grupo dominante, neste espaço ainda circulam conhecimentos e práticas de diferentes grupos, "nessa perspectiva, tendemos a concordar que educação desenvolvida nas escolas ocorre fora do mundo da vida" (MOURA; ZUCCHETTI, 2010, p. 636). Situações de segregação e de conflitos entre grupos diferentes no ambiente escolar contribuem para a ocorrência de atos discriminatórios, caracterizados como racismo institucional ou racismo sistêmico, considerado:

[...] a exclusão seletiva dos grupos racialmente subordinados - negr@s, indígenas, cigan@s, para citar a realidade latino-americana e brasileira da diáspora africana atuando como alavanca importante da exclusão diferenciada de diferentes sujeit@s nestes grupos (GELEDÉS - INSTITUTO DA MULHER NEGRA, 2016, p. 17).

Correa Xakriabá (2018) salienta que o racismo institucional acontece nos espaços institucionais e órgãos públicos e pode ser compreendido como ato de discriminação, tendo diversos motivos, como: a origem, cultura, identidade ou religião dos sujeitos discriminados. Em diversos casos pode não ser intencional, mas sim estrutural, manifestado por meio de pessoas que fazem parte ou utilizam estas organizações ou instituições.

No Brasil, é previsto na Constituição (1988) que a educação formal é um dos diretos fundamentais dos cidadãos. Neste sentido, o Estado não pode ser negligente e deve proporcionar uma educação inclusiva que agregue a todo um conjunto de culturas, considerando a multiplicidade étnica e cultural existente em nosso território.

O processo educativo deve ser dinâmico e ao mesmo tempo simbólico, adaptandose a cada comunidade, e produto da preocupação com a diversidade, com as identidades étnicas de cada grupo ou povo em que está imerso. Evidenciando a valorização da dimensão imaterial composta pelas;

Sensações, saberes, sentidos, sensibilidades e sociabilidades com que pessoas e grupos de pessoas atribuem socialmente palavras e ideias, visões e versões partilhadas ao que vivem, criam e fazem ao compartirem universos simbólicos que elas criam e de que vivem (BRANDÃO, 2009. p.717).

Moura e Zucchetti (2010, p. 646) expõem que não tomar como ponto de partida para a construção de uma educação escolar a realidade e as ações de cada grupo e indivíduos é Revista Cerrados, Montes Claros/MG, v. 18, n. 02, p. 344-370, jul./dez.-2020. 
MELO, L. J. R. C.; VAZ, A. D.; ALMEIDA, M. G.

Diferenças etnoculturais na escola: Experiências de alunos Xakriabá em um espaço escolar não indígena

cometer um equívoco, "Isso implica também romper com a certeza de que partilhamos um mundo comum com pontos de vista idênticos sobre uma realidade incontestável".

Para os grupos étnicos as regras de vivência e de convivência são perpetuadas de geração em geração, são as pessoas que pertencem aos grupos sociais e aos seus territórios, ao contrário do que ocorre em nossa sociedade (INCRA, 2015). Neste sentido, sentimentos de conservação da cultura, costumes e práticas de cada grupo tornam-se importantes, posto que são imprescindíveis para que efetivamente ocorra uma preparação educacional para a vida.

A escola, enquanto instituição, tem um papel fundamental para a construção do diálogo saudável entre estes grupos. Embora a escola não consiga resolver todas as questões relacionadas as situações de conflitos e/ou preconceito, ela possui um papel relevante dentro da sociedade e pode contribuir para a coexistência plena dos vários grupos étnicos, tanto dentro quanto fora do espaço escolar, "nesse sentido, a educação escolar, embora não possa resolver sozinha todas as questões, ocupa lugar de destaque em nossa sociedade e na discussão sobre a diversidade cultural” (MUNANGA, 1999 apud GOMES, 2003, p. 71).

Segundo Gomes (2003), é preciso conhecer as diferenças existentes na escola e respeitar todos os grupos, evidenciando-os e dando condições para que o preconceito e os estereótipos sejam desfeitos, pois, muitas vezes a falta de conhecimento acerca do outro pode gerar opiniões distorcidas que não condizem com a realidade.

Seguindo nesta perspectiva, Ramalho apresenta um dos princípios fundamentais na escola:

Logo, um dos principais propósitos da escola deve ser proporcionar uma educação pautada no reconhecimento das diferenças e na construção da igualdade, com objetivo de formar indivíduos atuantes na sociedade para que a mesma seja justa e democrática para todos. Sendo assim, a escola precisa priorizar o ensino e a aprendizagem sob o prisma de uma pedagogia pautada na democracia, que seja capaz de admitir existam existência das diferenças e valorizá-las, tendo em vista sempre a construção de uma nova sociedade, ajudando a transformar os alunos em seres solidários, respeitosos e capazes de conviver em união (RAMALHO, 2015, p. $35)$.

Essa autora explica que para ocorrer a quebra de paradigmas impostos pelo senso comum, que corroboram com o racismo e toda forma de intolerância, torna-se imprescindível o engajamento de todos que atuam no ambiente escolar e que as mudanças que precisam ser feitas ainda são muitas. A escola deve ser um espaço de troca de experiências entre os alunos, atendendo a todos, evitando situações de discriminação, exposição e humilhação. 
MELO, L. J. R. C.; VAZ, A. D.; ALMEIDA, M. G.

Diferenças etnoculturais na escola: Experiências de alunos Xakriabá em um espaço escolar não indígena

Uma educação pensada com enfoque na diversidade e na pluralidade foi e continua sendo um dos desafios para a educação brasileira, pois os dados e a própria mídia, evidenciam ainda muitos casos de intolerância no ambiente escolar motivados por diferenças etnorraciais e culturais.

\section{Etnia Xakriabá: um breve histórico do seu processo de escolarização}

$\mathrm{O}$ direito à representatividade sociocultural, acesso à educação tradicional e formal são primordiais para manter viva a história e os costumes ancestrais das comunidades indígenas. Rosa e Anaya (2016) e Correa Xakriabá (2018) afirmam que o povo Xakriabá compõe o maior grupo étnico indígena do estado de Minas Gerais. Embora o povo Xakriabá já estivesse presente no Brasil nos anos que antecederam a chegada dos primeiros europeus, Saint Hilaire (1975, p. 341 apud SANTOS 1994, p. 6) argumenta que ocorreu um agrupamento do povo Xakriabá após o século XVII, com outros grupos indígenas que viviam às margens do rio São Francisco, como também a miscigenação com grupos negros, quilombolas e mestiços que habitavam a região.

Todo o território tradicionalmente ocupado pela comunidade indígena Xakriabá localiza-se, de acordo com relatos desta população e documentos existentes, em uma área doada aos seus ancestrais no ano de 1728. Em reconhecimento ao apoio a Januário Cardoso de Almeida, combatendo a outro grupo indígena que vivia na região, os Kaiapó, “[...] em reconhecimento, obtêm, além da liberdade, um lote de terras delimitado pelos rios Itacarambi, Peruaçu e São Francisco, pela Serra Geral e Boa Vista. A área coincide com os limites atuais do município de Itacarambi, onde hoje se localiza o Posto Indígena Xakriabá” (SANTOS, 1994, p. 5).

As terras dos Xakriabá foram registradas no cartório de Ouro Preto no ano de 1856, mas somente no ano de 1978 uma porção das terras foi oficialmente demarcada e reconhecida como território indígena pelo governo, embora a homologação da posse da terra só tenha ocorrido em 1989. Correa Xakriabá (2018) apresenta que a etnia Xakriabá é composta atualmente por uma população de aproximadamente 11 mil habitantes, e as terras indígenas desse povo possuem uma área de cerca 54 mil hectares, entre área demarcada e homologada, dividida entre 35 aldeias, das quais duas estão em processo de retomada.

Cada uma das aldeias que compõem a comunidade indígena Xakriabá conta com Revista Cerrados, Montes Claros/MG, v. 18, n. 02, p. 344-370, jul./dez.-2020. 
MELO, L. J. R. C.; VAZ, A. D.; ALMEIDA, M. G.

Diferenças etnoculturais na escola: Experiências de alunos Xakriabá em um espaço escolar não indígena

comando próprio. A área da terra indígena demarcada localiza-se entre a região do AltoMédio São Francisco, composta predominantemente por uma área dentro dos limites do município de São João das Missões, “[...] comunidade localizada no norte do estado de Minas Gerais. O território Xakriabá, está localizado nas fronteiras dos Municípios de Itacarambi, São João das Missões, Cônego Marinho e Miravânia no estado de Minas Gerais.[...] São João das Missões, de acordo com as memórias do povo Xakriabá, era na verdade a antiga São João dos Índios” (CORREA XAKRIABÁ, 2018, p. 24), (ver mapa 1).

Mapa 1 - Localização do Território Xakriabá

\section{LOCALIZAÇÃO DAS TERRAS INDÍGENAS XAKRIABÁS}

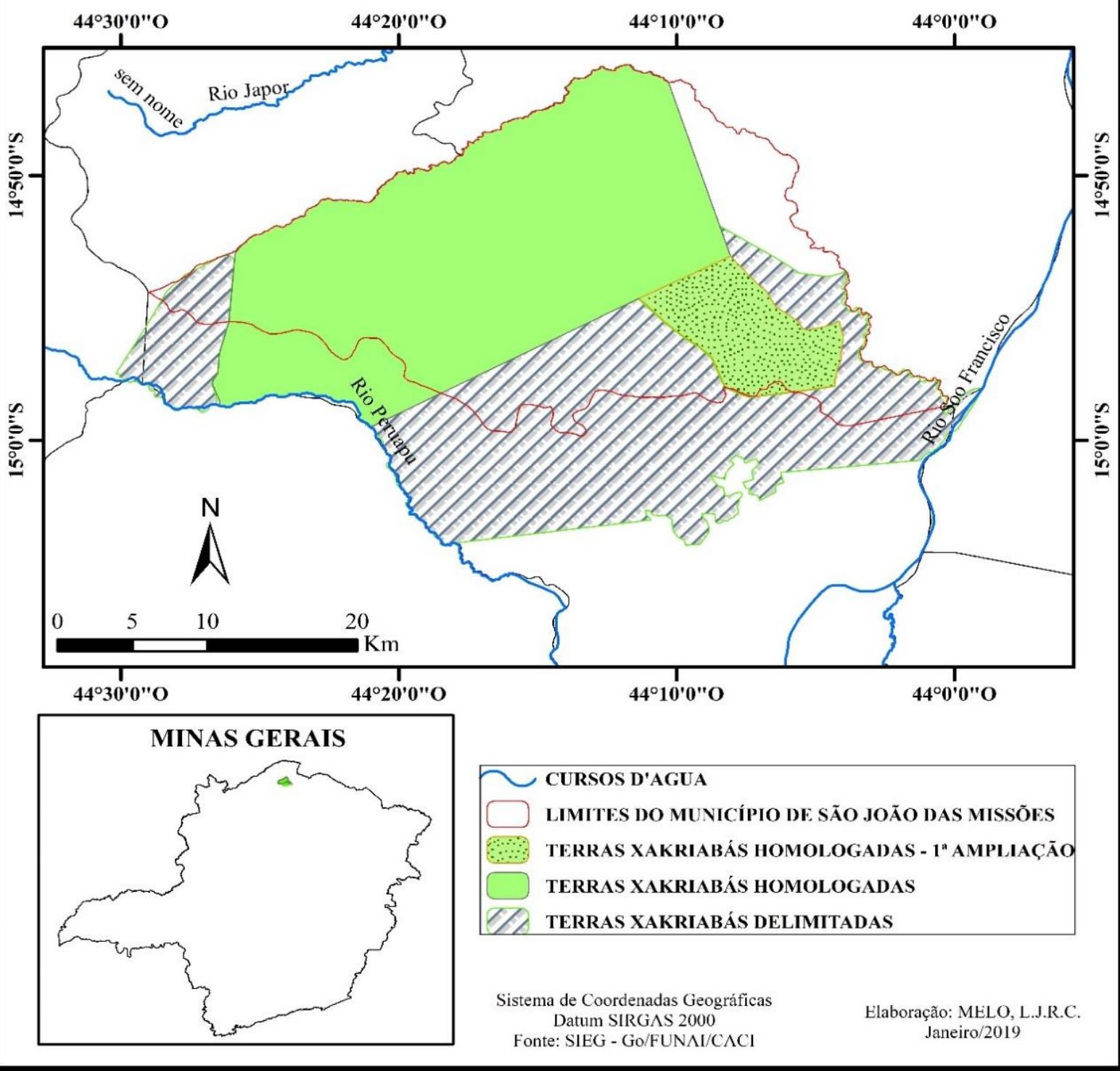

Fonte: SIEG/Go; FUNAI e CACI, 2019. Elaboração: MELO, L.J.R.C., 2019.

Revista Cerrados, Montes Claros/MG, v. 18, n. 02, p. 344-370, jul./dez.-2020. 
MELO, L. J. R. C.; VAZ, A. D.; ALMEIDA, M. G.

Diferenças etnoculturais na escola: Experiências de alunos Xakriabá em um espaço escolar não indígena

Fica evidente que desde o século XVIII o povo Xakriabá teve um intenso contato com os não indígenas, fazendo com que elementos da educação não indígena fossem gradativamente inseridos em sua comunidade. Correa Xakriabá (2018) analisa o processo de educação Xakriabá, dentro e fora da escola, denominando-o como um processo de "educação territorializada", pois este é permeado pela interação dos indígenas com o território, embora ressalte que a princípio o processo de educação tivesse um propósito colonizador.

Segundo Correa Xakriabá (2018), o processo de educação formal adentra a comunidade indígena Xakriabá no final do século XIX, com os dois primeiros leitores de cartas, alfabetizados em língua portuguesa, estendendo-se até os dias atuais. É importante a ressaltar o fato de que ao longo dos anos a comunidade Xakriabá tomou consciência da importância do processo educacional e passou a reivindicar cada vez mais uma educação que atendesse às suas necessidades, suas especificidades, enquanto cidadãos brasileiros e povo indígena.

Embora o processo de educação formal na comunidade Xakriabá tenha principiado, de forma bastante sutil, em meados do ano de 1856, somente no ano de 1978 o governo brasileiro buscou maneiras de alfabetizar os indígenas, seguindo os parâmetros institucionais, realizado dentro do território indígena por meio do Movimento Brasileiro de Alfabetização (MOBRAL), momento em que as aulas aconteceram nas casas dos indígenas.

No ano de 1987 foi instituída a primeira escola no território Xakriabá com aulas ministradas por professores não índios, somente dez anos após, no ano de 1997, ocorreu a substituição dos professores não indígenas por professores Xakriabá. A implementação de uma escola com professores indígenas só foi possível em consequência da instalação do Magistério Indígena (1996). Fato que oportunizou a formação acadêmica desses povos, desenvolvendo a primeira turma de professores indígenas para que atuassem em suas comunidades, despertando o interesse da comunidade indígena Xakriabá.

Após a formação dos primeiros professores Xakriabá, iniciou-se um processo de implantação de uma educação formal, mas ao mesmo tempo uma educação territorializada, despertando o interesse do povo Xakriabá em uma formação docente, "[...] é a grande quantidade de indígenas Xakriabá interessados neste tipo de formação.[..] 45 indígenas Xakriabá participaram do curso, enquanto as outras três etnias participantes somadas tiveram 21" (ALMEIDA, 2018, p. 12). Um processo de educação territorializada que leva em conta as demandas dessa comunidade articuladas ao território em que vivem. 
MELO, L. J. R. C.; VAZ, A. D.; ALMEIDA, M. G.

Diferenças etnoculturais na escola: Experiências de alunos Xakriabá em um espaço escolar não indígena

Após a construção da sede escolar (1998), no território Xakriabá, o processo de alfabetização indígena continuou e no ano de 2000, foi iniciada a primeira turma de $5^{\mathrm{a}}$ série, atual $6^{\circ}$ Ano. Entre os anos de 2004-2006 ocorreu a formação da terceira turma de alunos do magistério indígena. Em decorrência da formação da primeira turma de professores indígenas em ensino superior, no ano de 2006 foi instituído na escola indígena, também o ensino Médio, em sequência no ano de 2007, foi criado o cargo de professor de Cultura.

No ano de 2015 por meio do decreto $\mathrm{n}^{\mathrm{o}} 1$, no dia 7 de janeiro, foi instalado o primeiro magistério no território Xakriabá, atuando professores formadores indígenas. Entre os anos de 2015-2016 ocorreu a criação da Comissão Estadual de Educação Escolar Indígena (MG), momento que as atenções se voltavam sobre as discussões acerca da categoria Escola Indígena e de que forma a escola deveria receber e atender as demandas da comunidade Xakriabá.

\section{Etnia Xacriabá: a admissão o IF Goiano - Urutaí}

Ao evidenciar a preocupação que o povo Xakriabá possui com o processo de educação e escolarização formal, demonstra-se “[...] o grande interesse dos membros dessa etnia na chamada educação formal. É desse interesse e da oportunidade de se deslocar até o sudeste goiano que vem o contato desse povo com o IF Goiano - Campus Urutaí." (ALMEIDA, 2018, p. 13).

O IF Goiano - Urutaí, localiza-se a $2 \mathrm{~km}$ do perímetro urbano do município de Urutaí-GO, atualmente faz parte da Rede Federal de Educação Profissional, Científica e Tecnológica. As modalidades de ensino que o IF Goiano conta são: o Ensino Médio integrado a cursos técnicos, cursos de nível superior possibilitando a habilitação em bacharelado e licenciatura, assim como o Programa de Pós-Graduação, nível de especialização e mestrado.

O IF Goiano - Urutaí recebeu os primeiros alunos Xakriabá no ano de 2014 e continua a recebê-los até os dias atuais. Apesar do longo deslocamento realizado, no ano de 2018 o campus contava com um grupo de alunos Xakriabá de 28 indivíduos e ao final de 2019 eram 22 alunos. (Ver mapa 2). Os estudantes Xakriabá estão distribuídos do ensino médio integrado ao técnico até o ensino superior, almejando um processo de formação que vise atender às demandas de sua comunidade. 
MELO, L. J. R. C.; VAZ, A. D.; ALMEIDA, M. G.

Diferenças etnoculturais na escola: Experiências de alunos Xakriabá em um espaço escolar não indígena

Mapa 2 - Deslocamento realizado pelos alunos Xakriabá

\section{DESLOCAMENTO REALIZADO PELOS ESTUDANTES XAKRIABÁS}

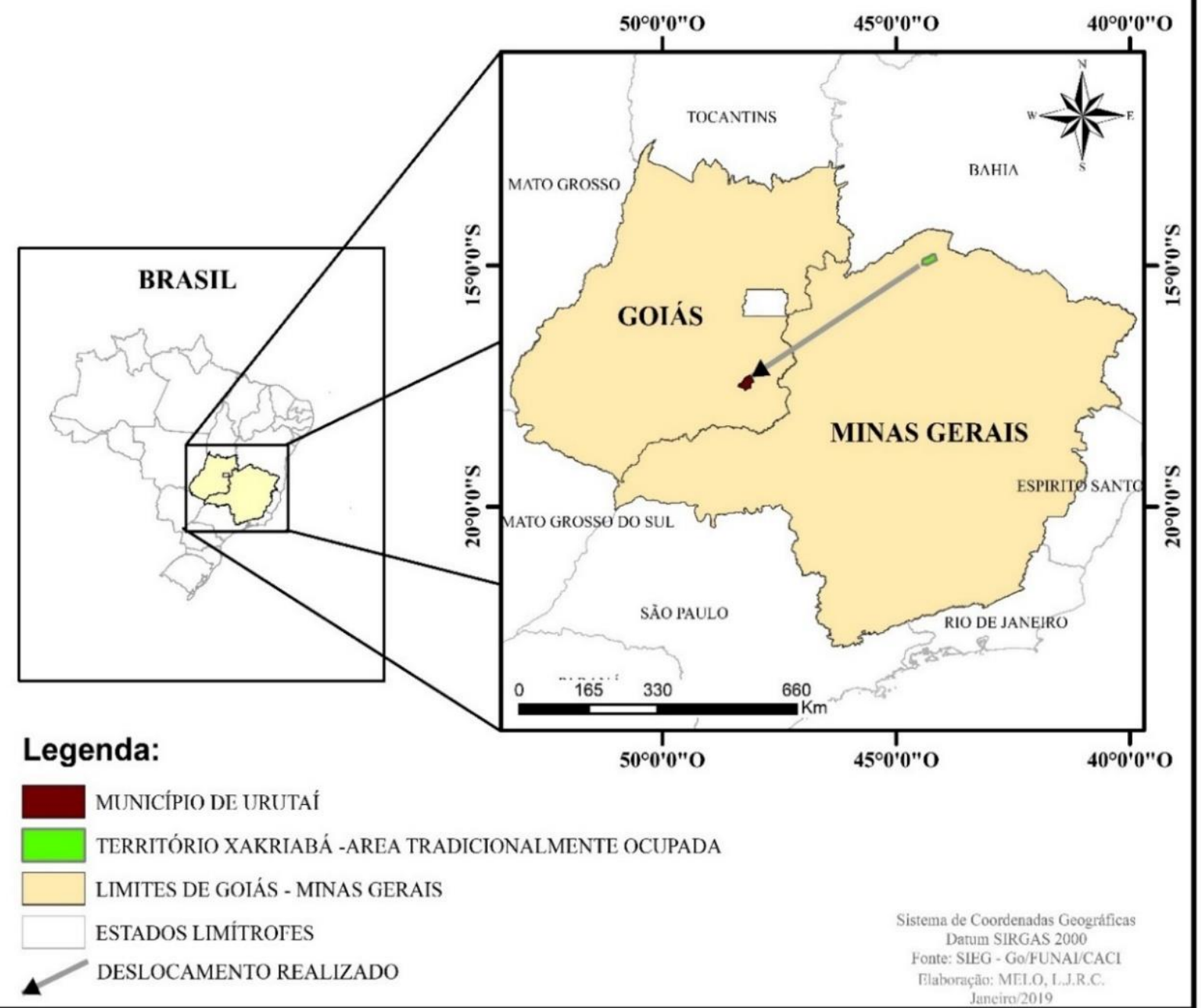

Fonte: Sistema Estadual de Geoinformação de Goiás, SIEG/Go, 2019.

Elaboração: MELO, L.J.C.M., 2019.

Os alunos Xakriabá, embora tenham acesso a escolas indígenas dentro de seus territórios, procuram ampliar seus conhecimentos acadêmicos "Meu sonho é ser médico, retornar para a reserva e ajudar meu povo', relata Lourisvânio'. Outra narrativa encontrada na página oficial do IF Goiano - Urutaí é o histórico do estudante, Daniel Oliveira, que concluiu seus estudos no final de 2017 com o objetivo de continuar sua qualificação em um curso superior para também atuar na comunidade. Atualmente é aluno do curso de Direito, na Universidade Federal de Goiás - UFG”. (Assessoria de Comunicação Social - Campus Urutaí, 
MELO, L. J. R. C.; VAZ, A. D.; ALMEIDA, M. G.

Diferenças etnoculturais na escola: Experiências de alunos Xakriabá em um espaço escolar não indígena

com Coordenação Geral de Comunicação Social, 2018)².

A partir do ano de 2014, começou a ser realizado um processo seletivo, decorrente da parceria entre o IF Goiano e a prefeitura de São João das Missões, pois, o atual prefeito desta cidade é um dos líderes Xakriabá,

A primeira década de 2000 é marcada por grande projeção do grupo no campo político. Nos últimos três mandatos, o povo Xakriabá alcançou o feito de eleger prefeitos indígenas e obter maioria na câmara municipal, além de circular e fazer-se ouvir pelos lugares mais diversos (SANTOS, 2010 apud ROSA; ANAYA, 2016, p. $15)$.

O processo de aquisição de poder político e de tomada de decisões, facilita a comunidade Xakriabá a reivindicar suas demandas, desse modo, o pleno acesso à educação escolar foi imprescindível, facilitando a possibilidade de formação de seus jovens. Os estudantes Xakriabá selecionados em suas comunidades para continuarem seus estudos no IF Goiano - Urutaí, recebem auxílio moradia e residem no próprio campus durante todo ano letivo. As visitas que realizam as suas aldeias no período de aulas, são restritas somente as férias de julho e janeiro.

\section{(Des)Encontros Entre Indígenas e Não Indígenas}

Uma questão central no contato com os alunos Xakriabá, era identificar se algum dos alunos já havia sofrido algum tipo de discriminação, por motivação étnica. Apenas três destes alunos responderam que nunca tinham sofrido este tipo de ato. Os outros sete alunos demonstram terem sofrido algum ato de discriminação em algum momento dentro do IF Goiano - Urutaí. Atos de discriminação, devem ser compreendidos neste contexto como atos e/ou tentativas de desmerecer, constranger e atacar de maneira perversa estes estudantes indígenas.

Segundo Rocha e Almeida (2005), atos de discriminação contra alguns grupos remontam de muito longe na história e pautam-se em preconceitos culturais cristalizados no imaginário de grupos detentores de um poder hegemônico, que buscam impor-se a outros grupos considerados inferiores.

\footnotetext{
${ }^{2}$ Disponível em: <https://www.ifgoiano.edu.br/home/index.php/component/content/article/189-ultimas-noticiasurutai/8603-xakriabas-buscam-formacao-para-atuacao-em-suas-aldeias.html>.

Revista Cerrados, Montes Claros/MG, v. 18, n. 02, p. 344-370, jul./dez.-2020.
} 
MELO, L. J. R. C.; VAZ, A. D.; ALMEIDA, M. G.

Diferenças etnoculturais na escola: Experiências de alunos Xakriabá em um espaço escolar não indígena

O aluno B relatou: "Eles falaram que eu não tinha um neurônio"; já o aluno D afirmou que "Apenas uma vez falaram que a gente não era índio, e ficaram fazendo piadas de mau gosto", no mesmo sentido o aluno I também respondeu "Falaram que a gente não era índio e ficaram fazendo piadas de mau gosto"; o aluno $\mathrm{J}$ foi mais enfático ao dizer: "Diariamente eles fazem aquelas brincadeirinhas sem graça. Começa zuando e debochando de nós. Ai pra evitar isso nós fica de boa, leva na brincadeira para não gerar conflitos". Pautando-se nas afirmações realizadas por estes alunos, evidencia-se que atos de discriminação e/ou bullying, praticados por alunos não índios contra alunos indígenas, existem no ambiente escolar.

Segundo Lima, Faro e Santos (2016, p. 219) “A inferiorização e desumanização da diferença é algo que acompanha a nossa história, marca os encontros intergrupais e opera integrando traços físicos e biológicos a teorias implícitas de personalidade", neste sentido, atos de discriminação contra o grupo indígena Xakriabá fazem parte de um processo de tentativa de inferiorização destes estudantes pelos alunos não índios.

Outra questão teve como propósito apontar se os alunos indígenas percebiam algum tipo de estranhamento por parte dos não índios, quando realizam práticas culturais que lhes são características em suas comunidades. As respostas se direcionaram no sentido que, tais práticas eram vistas com naturalidade pelos outros alunos, embora o aluno B ressalte que "Eles estranho ( $\mathrm{sic}$ ) porque não agente como pessoas normais, pensam que ainda somos como os nossos antepassados".

Fica evidente que os alunos não indígenas, ainda possuem uma visão estereotipada acerca do indígena, que arremete a construções imaginárias advindas de períodos coloniais, uma percepção do indígena enquanto um ser diferente, possuidor de modos considerados selvagens e não civilizados a típica visão do 'bom gentio'.

O processo de inferiorização da identidade indígena no espaço escolar é evidente. Para Lima, Faro e Santos (2016) esse processo ocorre quando características de determinados grupos são rechaçadas, por um outro, que se considera superior, prejudicando a possibilidade de uma convivência sadia. Embora nove alunos Xakriabá afirmassem que suas práticas tradicionais, como músicas e danças sejam vistas com naturalidade pelos alunos não índios, um aluno indígena diz que não.

Os alunos não índios ainda esperam que indígenas se apresentem como seus ancestrais, aquela velha imagem do índio selvagem, o típico estereótipo cristalizado no Revista Cerrados, Montes Claros/MG, v. 18, n. 02, p. 344-370, jul./dez.-2020. 
MELO, L. J. R. C.; VAZ, A. D.; ALMEIDA, M. G.

Diferenças etnoculturais na escola: Experiências de alunos Xakriabá em um espaço escolar não indígena

imaginário popular. Tal estranhamento justifica-se ao observar as colocações de Moura e Zucchetti (2010) que afirmam que as escolas muitas vezes se apropriam de valores socioculturais dos grupos hegemônicos e os coloca como padrões socialmente aceitos. Ao buscar detectar se os alunos Xakriabá já foram vítimas de algum tipo de violência física por parte dos alunos não indígenas, todos afirmaram que nunca sofreram nenhum tipo de violência física, no espaço escolar, protagonizada pelos não índios.

Na pesquisa objetivou-se saber como os alunos Xakriabá assinalam a existência de eventos realizados nas dependências do IF Goiano - Urutaí, em que pudessem participar e manifestar práticas culturais típicas de sua comunidade tradicional. A maioria relatou a existência de eventos em que isso ocorre: o aluno B aponta "Cão Guia"33; o aluno E "FECICE 4 e outros eventos"; já o aluno F complementa com "No FECICE, nós apresentamos um trabalho sobre a nossa cultura".

Um importante momento em que os estudantes Xakriabá tiveram a oportunidade de apresentar sua cultura aos não índios, foi durante o II Congresso de Educação e Seminário de Educação e Relações Étnico-Raciais, realizado no ano de 2018. O evento abordou a discussão de temas como a diversidade e suas interconexões com a educação, direcionando a realização de reflexões para temas relacionados à cultura e as demandas indígenas.

A partir dessas declarações é possível notar que existem momentos em que o IF Goiano - Urutaí abre espaço para que estes alunos possam apresentar algumas práticas culturais tradicionais para toda comunidade estudantil e acadêmica. (figura 1).

\footnotetext{
${ }^{3}$ O Programa Cão Guia teve origem no Núcleo de Atendimento às Pessoas com Necessidades Específicas NAPNE do Instituto Federal Catarinense Campus Camboriú, a partir da Secretaria de Desenvolvimento Humano da Presidência da República - SDH e da Secretaria de Educação Profissional e Tecnológica Setec/MEC. Foi expandido para outros IFs, entre estes o Campus Urutaí, e objetiva formar Treinadores e Instrutores de cães-guia, bem como treinar e fornecer estes animais a pessoas cegas ou de baixa visão, promovendo à inclusão destas pessoas.

${ }^{4}$ O Festival Científico Cultural Esportivo do IF Goiano (FECICE), traz como propósito apresentar resultados de pesquisas e projetos em andamento que são realizados pelos alunos e professores do Ensino Médio e Técnico, busca despertar nos discentes o interesse pela cultura e incentivar a prática esportiva.
}

Revista Cerrados, Montes Claros/MG, v. 18, n. 02, p. 344-370, jul./dez.-2020. 
MELO, L. J. R. C.; VAZ, A. D.; ALMEIDA, M. G.

Diferenças etnoculturais na escola: Experiências de alunos Xakriabá em um espaço escolar não indígena

Figura 1 - Apresentação cultural dos alunos Xakriabá no IF Goiano

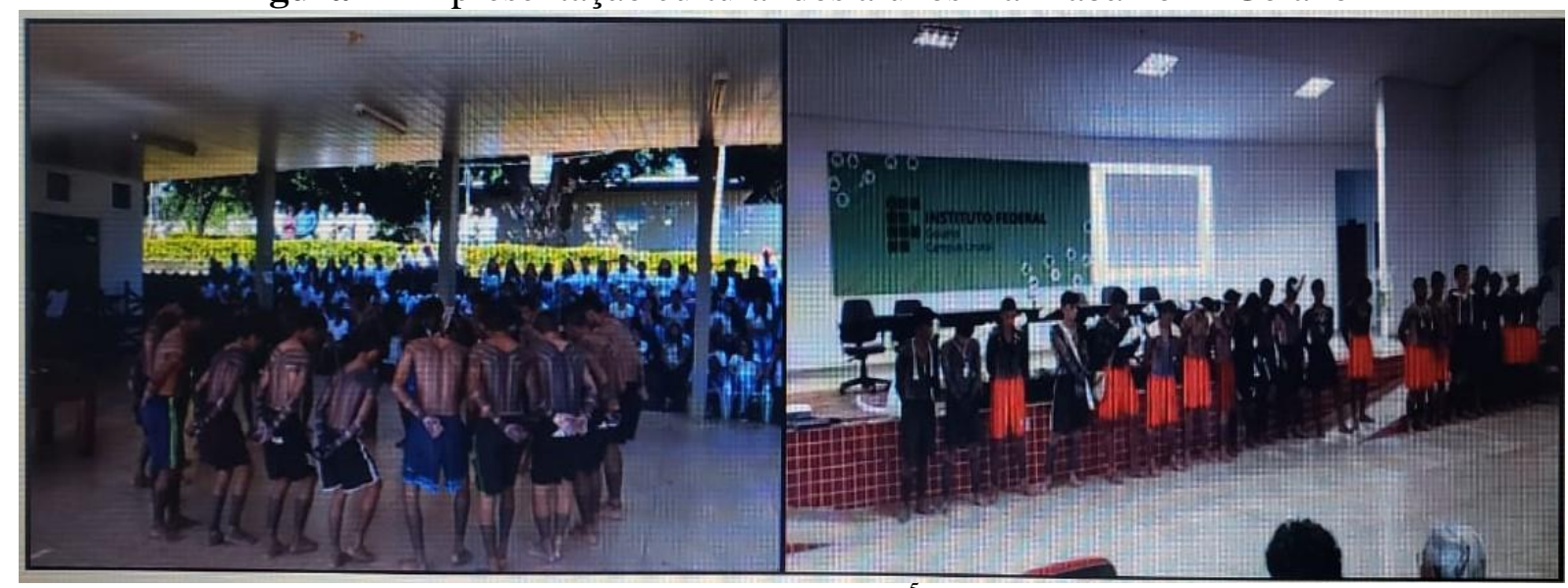

Fonte: Página do IF Goiano - Campus Urutaí no Facebook, $2019^{5}$.

Os eventos dessa natureza tornam-se importantes pois oferecem a oportunidade aos alunos indígenas de se expressarem enquanto povo indígena. Tais eventos são ferramentas poderosas ao combate dos estereótipos que datas comemorativas, como o Dia do Índio, 19 de abril, desperta no imaginário dos não indígenas.

Outra questão arremete quanto a representatividade que os alunos Xakriabá possuem neste espaço escolar, os resultados foram: dois alunos responderam que não se sentem representados; três responderam que se sentem representados; quatro alunos responderam que em alguns momentos tem representatividade e um aluno não respondeu.

O espaço escolar deve ser um espaço de representatividade, onde o diferente deve se fazer presente e sentir-se presente. De modo que explorar maneiras para que estes alunos se sintam parte importante dentro da comunidade escolar são determinantes no intento de proporcionar uma boa convivência entre alunos indígenas e não índios.

No que diz respeito às situações de conflitos entre os estudantes Xakriabá e os alunos não índios, sete afirmaram que tais situações inexistem; já três alunos Xakriabá confirmaram a existências de pontos de discordância entre eles e os alunos não índios, como evidencia o aluno J, "No caso das brincadeiras de mau gosto que ainda existem. Só que as veses (sic) levamos na brincadeira para não gerar muito conflito".

As situações que atestam a geração de conflitos entre os alunos indígenas e não indígenas, relatadas pelos estudantes Xakriabá, também podem ser consideradas atos de

\footnotetext{
${ }^{5}$ Conteúdo disponível na página oficial do Instituto Federal Goiano - Campus Urutaí em: <https://www.facebook.com/campusurutai/>.
} 
MELO, L. J. R. C.; VAZ, A. D.; ALMEIDA, M. G.

Diferenças etnoculturais na escola: Experiências de alunos Xakriabá em um espaço escolar não indígena

discriminação e preconceito, pois todo tipo de brincadeira que fere o sentimento do outro, que atenta contra a integridade física e/ou mental de alguém é considerado um ato discriminatório, e no espaço escolar bullying e agressão, como destaca a Lei 13.185 de 2015, que instituiu o Programa de Combate à Intimidação Sistemática (Bullying). De acordo com Souza e Almeida (2011), o tipo de agressão ocorrido, em todos os casos, provoca sofrimento, afetando até mesmo os processos de aprendizagem e socialização destes indivíduos e podendo gerar graves sequelas que prejudiquem a formação emocional.

Ainda de acordo com as autoras, as agressões suscitam uma geração de pessoas estressadas, deprimidas e com baixa autoestima, "baixa capacidade de auto-aceitação e resistência a frustração, reduzida capacidade de auto-afirmação e de auto-expressão, além de outras sintomatologias como doenças psicossomáticas e psicopatologias graves”. (SOUZA E ALMEIDA, 2011, p. 182).

Os alunos Xacriabá, se sentiam percebidos pelos alunos não indígenas no espaço escolar de uma maneira que pode ser preocupante: oito afirmaram que não são nem bem, nem mal vistos e apenas dois afirmaram que são bem vistos pelos colegas não índios. Cinco alunos asseguraram não haver nenhum tipo de dificuldade em uma interação entre eles; já os outros cinco, afirmaram a existência de dificuldades.

Destacando as ponderações realizadas por três destes alunos: aluno B "Trabalhos em grupo"; o aluno F "Dificuldade em interagir com eles" e aluno J "Eu só não me interesso por pessoas que não interage comigo. Aquelas que não gostam de nos índios. Fora isso eu interajo com muitas pessoas aqui tem muitas pessoas que gostam de nos". É importante destacar na posição do aluno J que sua interação se dá com todos que tenham interesse nessa relação, embora ele evidencie também a existência de pessoas que não gostam deles, enquanto alunos indígenas.

$\mathrm{Na}$ exposição do aluno J, este afirmou a existência de pessoas que não gostam de índios, fazendo com que a convivência destes dois grupos se torne ainda mais difícil, pois os alunos indígenas enfrentam uma realidade diferente de sua comunidade tradicional. Para os alunos Xakriabá conviver com pessoas que visivelmente, ou subjetivamente, deixam claro o seu evitar, apenas contribui para o distanciamento destes dois grupos. 
MELO, L. J. R. C.; VAZ, A. D.; ALMEIDA, M. G.

Diferenças etnoculturais na escola: Experiências de alunos Xakriabá em um espaço escolar não indígena

\section{Relação Indígenas e Não Índios: visão dos professores}

O período que estes profissionais exercem a atividade docente variou entre 2 anos, o profissional com menor tempo de atuação na docência, e 23 anos, o com maior tempo de atuação. Com relação a auto declaração de etnia/raça: três declaram-se pardas, três brancas, uma negra, uma humana, uma 'gente ${ }^{, 6}$ e três não fizeram nenhum tipo de declaração. Ao analisar a autodeclaração étnica dos professores, a diversidade étnico-racial faz-se presente entre estes profissionais, o que poderia facilitar o trabalho com questões relacionadas à diversidade em sala de aula.

Pelo menos a metade destes professores já presenciaram atos de discriminação e/ou bullying contra os alunos indígenas, protagonizado pelos alunos não indígenas, seis professores afirmaram que não. A declaração dos seis professores que alegaram já terem presenciado atos de discriminação e/ou bullying contra os alunos indígenas, serviu de sustentáculo para a afirmação de alguns estudantes Xakriabá, ao relatarem já terem sofrido atos desta natureza.

Indagados acerca da interação entre os alunos indígenas e não índios, tanto em sala de aula quanto nos espaços gerais da escola, seis professores concordaram que as relações são harmoniosas e se dão de maneira amistosa; porém, a outra metade afirmou que as relações entre estes dois grupos ocorrem de forma conflituosa. A partir destas respostas confirma-se, a ideia de que conflitos podem ser detectados, no encontro e na convivência destes dois grupos.

No ambiente escolar é perceptível atos de violência, que tenham como motivação diferenças étnicas: na opinião de quatro professores sim; quatro apontaram que não; dois professores alegaram já ter presenciado atos de violência que teve por motivação diferenças étnicas e apenas um professor manteve esta questão sem resposta.

Embora os estudantes Xakriabá declarem não terem sofrido atos de violência na escola, metade dos professores afirmou que são perceptíveis atos dessa natureza tendo como motivação diferenças étnicas, inclusive dois confirmaram ser testemunhas de tais atos. Seis professores responderam que trabalham com temas relacionados à diversidade, multiplicidade e pluralidade étnica em suas aulas; quatro não trabalham temas relacionados a esta temática e um destes profissionais afirmou que somente às vezes inclui este tipo de tema nas aulas.

\footnotetext{
${ }^{6}$ Foi utilizado a auto atribuição, em que o próprio sujeito registra sua resposta no formulário.
} 
MELO, L. J. R. C.; VAZ, A. D.; ALMEIDA, M. G.

Diferenças etnoculturais na escola: Experiências de alunos Xakriabá em um espaço escolar não indígena

Como exemplos: a professora A citou que realiza "Leitura de textos de autores africanos sobre a temática racial. Oficina sobre a temática racial, mas especificamente discutindo preconceito racial no nazismo (Leitura de Anne Frank)"; a professora D relatou utilizar temas como "Religiões - Seminários. Grécia Antiga - Mitos, rituais. Cultura Helenística Seminários"; a professora H afirmou "Sempre procuro promover nos alunos o sentimento de valorização cultural, fazendo com que os mesmos além do reconhecimento e respeito das diferentes culturas, tento mostrar que não existe uma melhor ou mais desenvolvida que a outra."; a professora J declarou fazer "Oficinas valorizando a cultura africana (etnomatemática). Jogos africanos p/o ensino da matemática”; já a professora L realiza "Leituras de textos de vários autores, principalmente da literatura africana, Discussões nas aulas de literatura, abordando o período de escravidão no Brasil. Discussões específicas da $1^{\text {a }}$ Geração Romântica e o papel do índio nos romances etc.”.

Faz-se importante ressaltar que os conteúdos relacionados à pluralidade e a multiplicidade cultural, no ensino básico, podem ser abarcados de maneira direta, quando estes fazem parte dos conteúdos programáticos das disciplinas. Mas, também podem, e devem, ser incluídos de maneira transversalizada por professores e professoras de qualquer uma das disciplinas, algo que está previsto nos Parâmetros Curriculares Nacionais (PCNs), até mesmo de forma multidisciplinar.

Junto aos professores buscou-se determinar de que forma eles classificariam as políticas de inserção de alunos indígenas, praticadas pelo IF Goiano - Urutaí: nove professores entendem ser de grande importância; dois consideram que são importantes, embora, não atinja a todos os alunos indígenas e um acredita que essas políticas são inexistentes. Apenas três professores afirmaram que não existe algum tipo de elemento ou situação que possa colaborar para a ocorrência de situações conflitosas entre os alunos indígenas e os não indígenas, os outros concordaram que sim, existe algum tipo de elemento ou situação.

No contexto do questionamento anterior, a professora A afirmou que "Embora não tenha presenciado conflitos, percebo que não há interação entre indígenas e não indígenas", a professora B relatou "Desempenho escolar, desrespeito a cultura indígena", a professora $\mathrm{C}$ ponderou que "Maior conscientização da parte de ensino tanto para os professores, quanto para os alunos. Assim os professores por exemplo, vão saber como começar o ensino com os alunos indígenas e com isso diminuiria as dificuldades dos Revista Cerrados, Montes Claros/MG, v. 18, n. 02, p. 344-370, jul./dez.-2020. 
MELO, L. J. R. C.; VAZ, A. D.; ALMEIDA, M. G.

Diferenças etnoculturais na escola: Experiências de alunos Xakriabá em um espaço escolar não indígena

mesmos". A professora J afirmou que "A própria convivência em sala de aula, sem ser estimuladas a interação, já se configura em uma situação de mal estar aos grupos indígenas".

Acerca da percepção dos professores sobre a maneira que os alunos indígenas são percebidos pelos alunos não índios no ambiente escolar: cinco professores relataram que os alunos indígenas são ignorados a maior parte do tempo; um acredita que eles são mal vistos; três concordaram que não são nem bem, nem mal vistos; dois alegaram que são bem vistos, e apenas um dos professores não respondeu.

Quanto à existência de dificuldades no processo de interação entre os alunos indígenas e não índios no espaço escolar, que pudessem ter sido observadas por estes professores: três não perceberam nenhum tipo de dificuldade; dois afirmaram que em alguns momentos percebem esta dificuldade de interação e o restante concordou que sim, existe situações que dificultam a interação entre estes dois grupos.

Ainda em relação à percepção de dificuldades de interação entre os alunos indígenas e não índios, os professores destacaram; professora A "não há, interação com a turma. São ignorados. Participam pouco das atividades" e a professora C, "Organização de equipes para trabalho; Momento de explicação do conteúdo ou momento de tirar dúvidas (os alunos não índios algumas vezes reclamam por ter que ir mais devagar ou pela falta de entendimento), mas isso é bloqueado no momento que o professor regente não aceita".

Outro momento de dificuldade de interação ocorre durante a realização de trabalhos em grupos, como observou a professora D, "Trabalho em equipe, indígenas são excluídos. Indígenas não tiram dúvidas sobre o conteúdo". Durante as aulas a professora E relatou algumas dificuldades enfrentadas pelos alunos indígenas, "Os alunos indígenas possuem dificuldades de interação até mesmo com os professores, uma vez que se sente retraídos e nem sequer faz perguntas". Já a professora K foi mais contundente em seu relato: "Na maior parte dos casos, não há interação entre diferentes grupos. Os indígenas se apresentam retraídos e acuados em situações comuns de sala da aula, como se não estivesse de fato integrados ao grupo".

\section{CONSIDERAÇÕES FINAIS}

Os levantamentos bibliográficos acerca do tema, revelam que, ao longo da história do Brasil, os encontros interétnicos desenrolaram-se, quase a totalidade, de maneira Revista Cerrados, Montes Claros/MG, v. 18, n. 02, p. 344-370, jul./dez.-2020. 
MELO, L. J. R. C.; VAZ, A. D.; ALMEIDA, M. G.

Diferenças etnoculturais na escola: Experiências de alunos Xakriabá em um espaço escolar não indígena

conflituosa. O grupo detentor do poder hegemônico, com a visão de mundo eurocêntrica, dominou outros grupos nativos e africanos considerados inferiores, num notório processo de inferiorização do outro, e até mesmo dizimando comunidades e culturas por inteiro.

No espaço escolar, a diversidade cultural e étnica deve ser observada enquanto catalisador de conflitos. Caso ocorra uma tentativa de valorização de culturas ditas versadas e eruditas neste espaço, deve-se buscar formas de valorizar toda a diversidade. No contexto do IF Goiano, é observável que existe uma tentativa por incluir os alunos indígenas no contexto de uma instituição escolar não indígena.

À luz dos dados coletados, fica evidente a complexidade das relações e dos encontros intergrupais, junto aos estudantes Xakriabá, pois, as diferenças etnoculturais são elementos que despertam conflitos, atos de racismo, preconceito e bullying no espaço escolar, entre os alunos indígenas e os não índios.

O espaço escolar, campo de estudo deste trabalho, apresenta-se enquanto um espaço que possibilita a representatividade cultural dos estudantes Xakriabá e observa-se momentos em que estes alunos podem se apresentar a toda a comunidade escolar enquanto indivíduos e grupo indígena. Algo que ocorre durante os mais variados tipos de eventos, saindo do ultrapassado estereótipo cultural que lembra dos grupos indígenas apenas em datas comemorativas, como 19 de abril, dia do índio contribuindo apenas para a conservação de preconcepções.

O principal aspecto observado que coopera para o aparecimento de conflitos, entre o grupo indígena e os não índios, está na deficiência dos alunos não índios em compreender a identidade dos povos originários brasileiros. Cabendo a gestão escolar apresentar formas de desmistificação da identidade indígena.

Visibilizando a importância dos alunos não índios compreenderem os valores simbólicos e subjetivos que só podem ser acessados a partir da convivência harmoniosa, do conhecimento do outro e da aceitação. Quanto a maneira como os alunos Xakriabá são vistos pelos alunos não índios, é perceptível que são ignorados. Tornando-se necessário visibilizar a cultura indígena.

Embora se tenha dado ênfase as experiências dos alunos indígenas, para se obter uma resposta mais aprofundada, acerca de como ocorre a convivência entre estes dois grupos de alunos, seria necessária uma investigação em conjunto com os alunos não indígenas, dada a complexidade do questionamento. 
MELO, L. J. R. C.; VAZ, A. D.; ALMEIDA, M. G.

Diferenças etnoculturais na escola: Experiências de alunos Xakriabá em um espaço escolar não indígena

Os resultados obtidos tornam-se importantes ao dar ênfase as vivências dos estudantes indígenas, em uma escola não indígena, cooperando para que a comunidade escolar veja a importância de explorar temas relacionados à pluralidade e a multiplicidade cultural. A comunidade acadêmica reflita acerca da importância do desenvolvimento de pesquisas que abordem as diferenças etnorraciais e etnoculturais no espaço escolar, contribuindo assim para a ampliação do conhecimento.

Faz-se importante repensar a educação e o espaço escolar numa perspectiva que leve em consideração o modo como ocorre a formação étnico-racial e cultural, no espaço escolar, pois, para preparar verdadeiros cidadãos deve-se conhecer a diversidade étnico-racial e a pluralidade cultural da população brasileira, assim como as respeitar

Estes resultados também colaboram também para que os gestores e políticos percebam a necessidade de discussões e da criação de políticas públicas destinadas a uma educação multicultural no Brasil. Além de demonstrar a relevância e pertinência da Geografia no desenvolvimento de pesquisas acerca desta temática.

\section{REFERÊNCIAS}

ALMEIDA, Ranna Iara de Pinho Chaves. Cultura Escolar Agrícola e Educação Escolar Indígena: vivências dos alunos Xakriabá no Instituto Federal Goiano - Campus Urutaí - GO. In. 31 ${ }^{a}$ Reunião Brasileira de Antropologia, realizada entre os dias 09 e 12 de dezembro de 2018, Brasília/DF. 2018. Disponível em: <http://www.evento.abant.org.br/rba/31RBA/files/1541462792_ARQUIVO_CulturaEscolarA gricolaeEducacaoEscolarIndigena.pdf $>$. Acesso em: 17 de out. de 2019.

BRANDÃO, Carlos Rodrigues. Vocação de criar anotações sobre a cultura e as culturas populares. Cadernos de Pesquisa, [S./1.], v. 39, n. 138, p. 715-746, set./dez. 2009.

INCRA - Instituto Nacional de Colonização e Reforma Agrária. Regularização de Território Quilombola: perguntas e respostas. Brasília, DF. 2018. Disponível em <http://www.incra.gov.br/sites/default/files/incra-perguntasrespostas-a4.pdf>. Acesso em: 30 de maio de 2018.

BRASIL. Constituição (1988). Constituição da República Federativa do Brasil. Brasília. 1988. Disponível em: <http://www.planalto.gov.br/ccivil_03/Constituicao/Constituicao.htm>. Acesso em: 26 de jan. de 2019.

\section{CAMPOS, V.; SILVA, A. L.; SILVA, D. R. A Formação do Povo Brasileiro e o}

Reconhecimento Efetivo da Diversidade: Cultura, educação e ações afirmativas em prol de uma sociedade reflexiva. Revista do Programa de Pós-graduação em Humanidades, Culturas e Artes, Rio de Janeiro/Unigranrio, v. 1, n. 15, p. 383-397, 2017. 
MELO, L. J. R. C.; VAZ, A. D.; ALMEIDA, M. G.

Diferenças etnoculturais na escola: Experiências de alunos Xakriabá em um espaço escolar não indígena

CANDAU, Vera Maria. Multiculturalismo e educação: desafios para a prática pedagógica. In: Moreira, A. Candau, V. (org.). Multiculturalismo: diferenças culturais e práticas pedagógicas. 2. ed. Petrópolis: Vozes. 2008 EU A RETIRARIA!

CORREA, Célia Nunes. O Barro, o Genipapo e o Giz no fazer epistemológico de Autoria Xakriabá: reativação da memória por uma educação territorializada. Célia Nunes Correa Xakriabá. Brasília - DF, 2018. 218 f. Dissertação (Mestrado Profissional em Sustentabilidade junto a Povos e Terras Tradicionais - MESPT), Centro de Desenvolvimento Sustentável, Universidade de Brasília, Brasília, 2018.

GELEDÉS - INSTITUTO DA MULHER NEGRA (Brasil). Racismo Institucional Uma Abordagem Conceitual. 2016. Disponível: <http://www.onumulheres.org.br/wpcontent/uploads/2016/04/FINAL-WEB-Racismo-Institucional-uma-abordagemconceitual.pdf >. Acesso em: 11 de abr. de2019.

GIL, Antônio Carlos. Métodos e técnicas de pesquisa social. 6. ed. - São Paulo: Atlas, 2008.

GOMES, Nilma Lima. Educação e Diversidade Étnico-Cultural. In BRASIL. Diversidade na educação: reflexões e experiências. Secretaria de Educação Média e Tecnológica. Brasília. 2003. Disponível em: <http://forumeja.org.br/sites/forumeja.org.br/files/Diversidade-naeducaCAo-reflexOes-e-experiEncias_Marise_Ramos.pdf\#page=69>. Acesso em: 06 de mai. de 2019

LIMA, Marcus Eugênio Oliveira. FARO, André. SANTOS, Mayara Rodrigues dos. A desumanização presente nos estereótipos de índios e ciganos. Revista Psicologia Teoria e Pesquisa, [S./l.], v. 32 n. 1, p. 219-228, Jan-Mar 2016.

MOURA, E. P. G.; ZUCCHETTI, D. T. Educação além da Escola: Acolhida a outros saberes. Cadernos de Pesquisa, [S./l.], v.40, n.140, p. 629-648, maio/ago. 2010. Disponível: <http://www.scielo.br/pdf/cp/v40n140/a1640140.pdf>. Acesso em: 10 de abril de 2018.

RAMALHO, Lays da Silva. Diversidade cultural na escola. Diversidade e Educação, [S./l.], v.3, n.6, p. 29-36, jul./dez. 2015.

RIBEIRO, Darcy. O povo brasileiro: a formação e o sentido do brasil. 2 ed. Companhia das Leras. 1995. Disponível em: <http://www.iphi.org.br/sites/filosofia_brasil/Darcy_Ribeiro__O_povo_Brasileiro-_a_formação_e_o_sentido_do_Brasil.pdf $>$. Acesso em: $11 \mathrm{de}$ abr. de 2019.

RIBEIRO, Solange Lucas. Espaço escolar um elemento (in)visível no currículo. Sitientibus, Feira de Santana, n 31, p. 103-118, Jul./dez. 2004. Disponível em:

<http://www2.uefs.br/sitientibus/pdf/31/espaco_escolar.pdf>. Acesso em: 3 de mai. de 2019.

ROCHA, Lurdes Bertol. ALMEIDA, Maria Geralda. Cultura, mundo-vivido e território. In . Simpósio nacional sobre geografia, percepção e cognição do meio ambiente. 2005.

Disponível em: <https://geografiahumanista.files.wordpress.com/2009/11/lurdes.pdf>. Acesso em 14 de abr. de 2019. 
MELO, L. J. R. C.; VAZ, A. D.; ALMEIDA, M. G.

Diferenças etnoculturais na escola: Experiências de alunos Xakriabá em um espaço escolar não indígena

ROSA, H. S.; ANAYA, F. C. Raiz que sustenta a nossa identidade. Revista Agriculturas, [S./1.], v. 13 - n. 1, p. 13-17, março/2016. Disponível em:

<http://aspta.org.br/files/2016/06/Agriculturas_V13N1_Comunica\%C3\%A7\%C3\%A3o.pdf>. Acesso em: 6 de nov. de 2019.

SANTOS, A. F. M. XAKRIABÁ: Identidade e história. Relatório de pesquisa. Pós-

graduação (Mestrado). Programa de Pós-Graduação em Antropologia Social da Universidade de Brasília, em nível de Mestrado. Brasília. 1994. Disponível em:

<http://dan.unb.br/images/doc/Serie167empdf.pdf>. Acesso em: 17 de jul. de 2019.

SILVA, G.; LOPES, C. S. Topofilia e topofobia: um estudo da percepção ambiental de Alunos do ensino médio em Paiçandu - PR. In. Os desafios da escola pública paranaense na perspectiva do professor PDE. Paraná. 2014. Disponível em:

<http://www.diaadiaeducacao.pr.gov.br/portals/cadernospde/pdebusca/producoes_pde/2014/2 014_uem_geo_artigo_gerson_da_silva.pdf >. Acesso em: 4 de mai. de 2018.

SILVEIRA, R. S.; NARDI, H. C. Interseccionalidade gênero, raça e etnia e a lei Maria da Penha. Psicologia \& Sociedade, [S./l.], 26(n. spe.), 14-24. (2014). Disponível em:

<https://www.lume.ufrgs.br/bitstream/handle/10183/147307/000993659.pdf?sequence=1\&is Allowed=y>. Acesso em: 02 de mai. de 2019.

SOUZA, C. P.; ALMEIDA, L. C. P. Enciclopédia biosfera. Centro Científico Conhecer Goiânia, v.7, n.12; 2011. Disponível em:

<http://www.conhecer.org.br/enciclop/conbras1/bullying.pdf>. Acesso em: 6 de nov. de 2019.

SUERTEGARAY, D. M. A. Notas sobre a epistemologia da Geografia. Cadernos

Geográficos, Florianópolis, n. 12, p. 1-63, maio 2005. Disponível em:

<http://cadernosgeograficos.ufsc.br/files/2016/02/Cadernos-Geográficos-UFSC-Nº-12-Notassobre-a-Espistemologia-da-Geografia.-Maio-de-2005.pdf>. Acesso em: 02 de maio de 2019.

VIÑAO FRAGO, Antonio; ESCOLANO, Agustín. Currículo, espaço e subjetividade: a arquitetura como programa. 2. ed. Rio de Janeiro: DP\&A, 2001. Disponível em: <http://www.edufrn.ufrn.br/bitstream/123456789/130/41/ARQUITETURA\%20COMO\%20P ROGRAMA.\%20Currículo\%2C\%20espaço\%20e\%20subjetividade.\%20FRAGO\%2C\%20An tonio.\%20ESCOLANO\%2C\%20Austín.\%202001pdf>. Acesso em: 3 de mai. de 2019.

\section{Autores}

Leonardo Jose dos R. C. de Melo - É Graduado em Geografia pela Universidade Estadual de Goiás (UEG). Atualmente é Mestrando do Programa de Pós-Graduação em Geografia (IESA) da Universidade Federal de Goiás (UFG). 
MELO, L. J. R. C.; VAZ, A. D.; ALMEIDA, M. G.

Diferenças etnoculturais na escola: Experiências de alunos Xakriabá em um espaço escolar não indígena

Ademir Divino Vaz - É Graduado e Mestre em Geografia pela Universidade Federal de Goiás (UFG). Atualmente é Professor da Universidade Estadual de Goiás (UEG) - Campus de Pires do Rio.

Maria Geralda de Almeida - É Graduada em Geografia pela Universidade Federal de Minas Gerais (UFMG), Mestrado e Doutorado em Geografia pela Université de Bordeaux III, pós doutorado em Geografia Humana pela Universidad de Barcelona, em Geografia Cultural pela Université Laval, Universita Degli Studi Di Genova e Universite de Paris IV Paris-Sorbonne. Atualmente é Professora do Programa de Pós-Graduação em Geografia (IESA) da Universidade Federal de Goiás (UFG).

Artigo recebido em: 08 de abril de 2020.

Artigo aceito em: 30 de setembro de 2020.

Artigo publicado em: 13 de novembro de 2020. 